\title{
Organizational Commitment, Organizational Justice and Work Satisfaction: A Comprehensive Model in a Romanian Organizational Setting
}

\author{
Zsolt E. Veress $^{1 *} \&$ Alin Gavreliuc ${ }^{1}$ \\ ${ }^{1}$ Department of Psychology, West University of Timişoara, Romania.
}

Received 27.09.2018; Received revised 18.12.2018; Accepted 22.12.2018

Available online 31.12.2018

\begin{abstract}
Our paper investigates the way in which the different dimensions of organizational justice and organizational commitment are mediated by work satisfaction. The rationale of the study is two folded. First, in our opinion there is a gap in scientific literature when it comes to studies that explore the way in which the dimensions of organizational justice and organizational commitment interact, most researches treating commitment as an aggregate concept. Second, even thou the interaction between organizational justice, job satisfaction and organizational commitment is well documented, studies that consider job satisfaction a mediator rather than an outcome variable are few even, if these few provide strong evidence regarding the value of job satisfaction as a mediator. Our research was done two Romanian manufacturing organization, in Harghita and Brașov Counties $(\mathrm{N}=676)$ and the collected data was interpreted using exploratory factor analysis and structural equation modeling. The obtained model not only further enforces existing body of knowledge regarding the strong relation between organizational justice and commitment but also proposes a way in which the dimensions of these two concepts relate to each other, relation that is mediated by job satisfaction. Our proposed model shows that three of the four dimensions of organizational justice (procedural, distributive, interactional justice) are mediated by job satisfaction (distributive justice) and one is partially mediated (procedural).
\end{abstract}

Keywords: organizational justice, job satisfaction, organizational commitment.

Address of correspondence: Zsolt Veress, Department of Psychology, West University of Timişoara, Bld. V. Pârvan nr. 4, Timișoara, 300233, Romania.

E-mail: veresszs@gmail.com

\section{Introduction}

The fact that the dimensions of procedural justice, job satisfaction and organizational commitment are linked is undeniable, as numerous researches from the last two decades have proven it, however what is not precisely clear is the exact way in which they influence each other, and what the exact relations between the different dimensions of the constructs are.

There are numerous researches, as supported by several meta-analysis in the field (Colquitt, Conlon, Wesson, Porter, \& Ng, 2001) that describe the relation between organizational justice and organizational commitment, reporting correlations between the two concepts between .48 and .61 , however even if the link between the two constructs is well established, the way in which they relate to each other is not very clear. Research has shown, that this relation can be mediated by constructs like organizational structure (Ambrose \& Scminke, 2003), organizational trust (Aryee, Budhwar, \& Chen, 2002), perceived organizational support (Otto \& Mamatoglu, 2015; Loi, Ngo, \& Foley, 2006) and also job satisfaction (Fulford, 2005). Most of these researches however investigate relations between the general concepts, without trying to observe interactions between the dimensions of the constructs treating the outcome variable, for example organizational commitment, as an aggregate score form (Cheng, 2014; Fulford, 2005; Ma, Xing, Wang, \& Chen, 2013; Crow, Lee, \& Joo, 2012). The present study attempts to contribute to the field by exploring the interactions between the dimensions of the targeted constructs through structural equation modeling, but also taking into consideration mediating factors, in this case job satisfaction. The use of job satisfaction as a moderator can also be considered an unorthodox approach and a contribution, as most studies (Bakhsi, Kumar, \& Rani, 2009; Lambert, Hogan, \& Griffin, 2007; Lowe \& Vodanovich, 1995) tend to consider this concept as an 
outcome variable on the same level with organizational commitment rather than a mediator.

\section{Theoretical framework}

The According to Greenberg and Lind organizational justice describes, (1987), the way people perceive justice inside an organization. Research focused on organizational justice has a long tradition in American organizational psychology, where the construct was first developed in the 90's by psychologists Adams and Greenberg (1986) by applying equity theory concepts to an organizational setting. In general as Byrne and Kiersch (2013) state, social-psychologists studying organizational justice incline to agree that there are three to four prominent forms of fairness perception: distributive justice, defined as the fairness of the results obtained by the employee through his/hers interactions as a product of decisions procedures/actions undertaken by employers in accordance with organizational policy; procedural justice, defined as the perceived fairness of the policies and procedures used to make decisions (Greenberg, 1986); and interactional justice. From all of the dimensions of organizational justice, this particular one, which from a chronological standpoint is the newest dimension, is also the most contested one. Originally this particular dimension was proposed by Bies and Moag in which they define interactional justice as the extent to which individuals see their leaders as being fair, sincere and having logic or rationale for what they do (Bies \& Moag, 1986) or in other words how fairly treated does a particular employee feel by his supervisor when procedures are enacted. Bies then updated his conceptualization of the original concept stating that "...people are concerned about interpersonal treatment in their everyday encounters in organizations. Interactional concerns transcend formal decision-making contexts..." (Roch\&Shanock 2007 apud Bies 2001). Colquitt re-conceptualized Bies's interactional justice as interpersonal justice and included the new sub dimension of informational justice that targets the way procedures are explained by supervisors to their subordinates (Colquitt $\mathrm{J}$. A., 2001). Based upon the updated definition of Bies, Roch and Shanock proposed a new scale to asses this particular dimension, scale that was used in the present paper.

Organizational commitment until the late 80's was viewed, as Mowday, Steers and Porter (1979) summarized, from a behavioral or an attitudinal angle, however at the beginning of the 90's Meyer and Allen (1991) suggested a new point of view that since became the status quo of organizational commitment research. The construct was split into three sub dimensions: affective commitment, defined as the reflection of the employee's emotional attachment to, identification with and involvement in the organization; normative commitment, defined as the employees feeling of obligation to remain with an organization; and continuance commitment, defined as recognition of the costs associated with leaving the organization (Meyer, Irving, \& Allen, 1998).

As the meta-analysis of Colquitt and al. (2001) exemplifies, procedural justice is positively linked to organizational commitment, a conclusion that is also supported on an international level (Cheng, 2014; Yang, Peng, \& Mossholder, 2004). However when it comes to the relation between the dimensions of the two constructs (procedural justice, distributive justice interactional justice, affective commitment, normative commitment and continuance commitment), things get more complicated. One of the most comprehensive enquiries regarding this subject was made by the meta-analysis of Charash and Spector (2001), who concluded that the strongest link is between affective commitment and procedural justice, distributive and interactional justice, followed by continuance commitment that was related to procedural and interactional justice, and last but not least, normative commitment that was linked procedural justice. When it comes to the role that satisfaction has, when talking about organizational justice and organizational commitment, results vary. We know that satisfaction is linked to both constructs (Gillet, Colombat, Micinov, Pronost, \& Fouquereau, 2013; Tang \& Strasfield-Baldwin, 1996; Ma, Xing, Wang, \& Chen, 2013; Tuzun, 2009; Patrick \& Sonia, 2012; Kwantes, 2009) but most research that centers on all three concepts usually does not treat satisfaction as a mediator. In itself job satisfaction is among one of the most commonly measured constructs in industrial and organizational psychology and was tied to attendance at work (Mobely, 1977), decision to retire (Scmitt \& McCunde, 1981), turnover (Hom \& Kincki, 2001)etc. Job satisfaction can be defined, according to Verecellino (2008), as a construct that refers to what people feel regarding their job, and the different modalities in which employees perceive their work as satisfactory or as unsatisfactory.

In those cases where job satisfaction is not treated as a mediator, usually the strongest link is established between distributive justice and satisfaction (Martin \& Bennet, 1996; Lee, An Empirical Study of Organizational Justice as Mediator of the Relationship among Leader-Member Excahnge and Job Satisfaction, Oganizational Commitment, and Turnover Intentions in the Lodging Industry, 2000) and procedural justice and commitment (McFarlin \& Sweeney, 1992; Konovsky \& Folger, 1989; Lee, 2000). However, when satisfaction is treated as a mediator, the reported results do not give a definitive answer regarding the strength of the mediation between the dimensions of organizational justice and the dimensions of organizational commitment. Crow at al. (2012) indicates that satisfaction is a better mediator between distributive justice and commitment, whilst the research of Fulford (2005), shows that satisfaction is a better mediator between procedural justice and commitment. It is worth mentioning that studies which would attempt to propose a model focusing on the relationship between the dimensions of organizational justice and the dimensions of organizational commitment mediated by job satisfaction are virtually nonexistent. A study that targets all previously mentioned concepts, minus normative commitment, was done by Darie (2011) in Romanian educational environment; however the study stops at finding correlations between them, reporting strong correlations between affective commitment and the dimensions of organizational justice ( .48 in case of procedural justice and distributive justice, and .47 in case of interactional justice, $\mathrm{p}<.01$ ), followed by correlations between job satisfaction and the dimensions of organizational justice ( .38 in case of distributive justice, $\mathrm{p}<.01 .26$ in case of procedural justice $\mathrm{p}<.05, .22$ in case of interactional justice $\mathrm{p}<.05$ ), and correlations between affective commitment and interactional commitment (.27, $\mathrm{p}<.05$ )

Thus the objective of the present study is to suggest a more comprehensive model of the relation between organizational justice, organizational commitment mediated by job satisfaction.

The hypotheses of the study are: 
H1. Job satisfaction will mediate the relationship between organizational justice and organizational commitment.

H2. Job satisfaction will mediate the relation between procedural justice and organizational commitment.

$H 3$. Job satisfaction will mediate the relation between distributive justice and organizational commitment.

H4. Job satisfaction will mediate the relationship between interpersonal justice and organizational commitment.

H5. Job satisfaction will mediate the relationship between informational justice and organizational commitment.

\section{Method}

\section{Participants and Procedure}

The study took place in two organizations one with $100 \%$ Romanian capital, and one that is the local branch of a major international corporation, both organizations focusing on manufacture. The studies were organized with the help of the management, participation was voluntary, anonymous, and special steps were taken to insure the privacy of the responses gathered. To versions of the questionnaires were administered. In case of the workforce the authors personally red the questions to groups of workers, and the participants marked their answers on a response sheet. In case of management full versions of the questionnaires were given which then were collected in a specially designed sealed ballot box opened only after the conclusion of the time allocated for the field study. Only the authors of the study have seen the response sheets and the questionnaires. The managements of the companies received only a statistical analysis of the end results. Sample sizes and sampling methodology was done according to the guidelines of Earl Babbie (2008).

The first organization (organization A) where study took place had at the time of the survey a total of 1100 employees of which approximately 1020 were active. The remaining 80 where absent due to maternity or sick leave, or their contracts were in process of termination, thus the representative sample was calculated was calculated according for 1000 employees with a confidence level of $95 \%$ and a confidence interval of \pm 4 . This resulted in a sample of 375 . The total number of questionnaires filled out by the employees was of 370 .

The second organization (organization B) where the study took place had at the time of the survey a number of 1800 employees of which 1700 were active. The remaining 100 were absent due to maternity or sick leave or their contracts were in process of termination, thus a representative sample was calculated for 1700.with a confidence level of $95 \%$ and a confidence interval of \pm 4 .

The total number of questionnaires filled out by the employees was of 350. Full sample size was not achieved due to time and production constrains that originated in the factory itself being understaffed thus having a considerable backlog that made achieving full sample size impossible.

The first organization is situated in Harghita county thus $94 \%$ of the people who took part in the study are Hungarian speaking, and the second study took place in the county of Braşov thus $93.3 \%$ of the people that took part in the study are Romanian speaking. The differences are also visible when it comes to religion which also reflects the cultural differences of the two populations. In the first case we have $79 \%$ Catholics, $4.3 \%$ Protestants $9 \%$ Greek
Orthodox and $1.4 \%$ other confessional factions, and in the second case we have $86.9 \%$ Greek Orthodox, 6.4\% Catholics, 2.7\% Protestants and 4\% other confessional factions. Differences can also be observed in the education of the populations but these are related to the specific activities of the two organizations.

\section{Measures}

For measuring the concepts the present study used the Colquitt Organizational Justice Scale, Meyer and Alan Organizational Commitment Scale and Warr, Cook and Wall's Job Satisfaction Scale.

The original Colquitt Organizational Justice Scale (2001) has 20 items that are evaluated on a Likert scale with scores between 1 (complete disagreement) and 7 (complete agreement). However because of the scope of this research the subscale measuring interactional justice was expanded by including the interpersonal justice scale developed by Roch and Shanock (2006) that contains 4 items developed based upon Bies's updated definition of the concept but also keeping Colquitt's items measuring informational justice. The scale created by Colquitt is widely used to measure organizational justice for example: Cole, Berneth, Walter and Holt (2010), Scott and Colquitt (2007), Zapata-Phelan, Colquitt, Scott and Livingston (2009).

For measuring job satisfaction the P.Warr, J.Cook and T. Wall (1979) Scale was used, which in itself is part of a larger questionnaire that measures constructs like job motivation, life satisfaction, happiness etc. and of course job satisfaction. In this present case only the items regarding job satisfaction were used which contained 2 subscales measuring intrinsic and extrinsic motivation using a 7 point Likert scale. The scale was used in several studies a few examples being: Heritage, Pollock and Roberts (2015), Saksvik and Hetland (2011).

For measuring organizational commitment, the used scale was the updated Allen and Meyer (2004) Scale. All items were measured using a 7 point Likert scale. The scale uses three subscales measuring normative, affective and continuance commitment. The scale itself was used and adapted in several studies and context, like: Chang, Chi and Miao (2007) or Blau, Andersson, Davis, Daymont, Hocher, Koziara, Portwood, and Holladay (2008).

\section{Results}

The first step in the analysis of the data was identification of outliers, process that was done according to the indications of Pallant (2005). A total of 50 (20 in the first organization, and 30 in the second organizations) questionnaires were identified as containing outliers, at all scales thus the decision was made to remove them from the data analysis.

For the analysis of the obtained data, we have used SPSS v.22 and AMOS v.22. When presenting the results of the analysis, the present paper uses the guidelines recommended by Pallant (2005), Howitt and Cramer (2010). Due to the fact that $95 \%$ of the employees were Hungarian speaking, the three scales had to be adapted, as no Hungarian versions of the questionnaires were found. Because of this, for all three scales we have done a confirmatory factor analysis through structural equation modeling. In case of the organizational justice scale our model, with 4 predetermined eigenvalues as suggested by theory, achieved statistical significance with an 
$\mathrm{X}^{2}=506.005, \mathrm{p}>.000$, a RMSEA score of .077 , and a CFI of .84 , and a GFI of .88 .

In case of the Warr and Cook Job Satisfaction Scale both models had an $\mathrm{X}^{2}<.05$, but the three factor model had a RMSEA of .06 and a CFI of .88 and the two factor model had a RMSEA of .07 and a CFI of .88.The results with the three factor model are in line with those reported by Heritage and Pollock (2015) but the 2 factor model presented here obtained marginally better results than those of the previously mentioned authors (RMSEA .084, CFI .86). For the purpose of the present study we will only use the global job satisfaction score.

In case of the organizational commitment scale we predetermined 3 eigenvalues as suggested by theory. The model achieved statistical significance having $X^{2}=385.753$ $\mathrm{p}>.000$, a RMSEA of .068., GFI of .884 and CFI of .868 , which are in line with the results reported by Chang, Chi, Miao (2006).

All the aforementioned results are presented in Table 2 while internal consistency indices for the whole sample are presented in Table 3.
Table 3. Internal consistency indices

\begin{tabular}{ll}
\hline Dimension & $\alpha$ coefficient \\
\hline Colquitt Organizational Justice Scale & \\
Distributive justice & .825 \\
Procedural justice & .816 \\
Interpersonal justice ( Roch \& Shanock, & .473 \\
2006) & \\
Informational justice & .846 \\
Total scale & .885 \\
\hline Meyer and Allen Organizational Commitment Scale \\
Normative commitment & .714 \\
Affective commitment & .701 \\
Continuance commitment & .801 \\
Total scale & .874 \\
\hline Warr\&Cook Sources of Satisfaction Scale & \\
Internal sources of satisfaction & .849 \\
External sources of satisfaction & .810 \\
Total scale & .906
\end{tabular}

Table 1. Descriptive statistics of sample $(\mathrm{N}=676)$

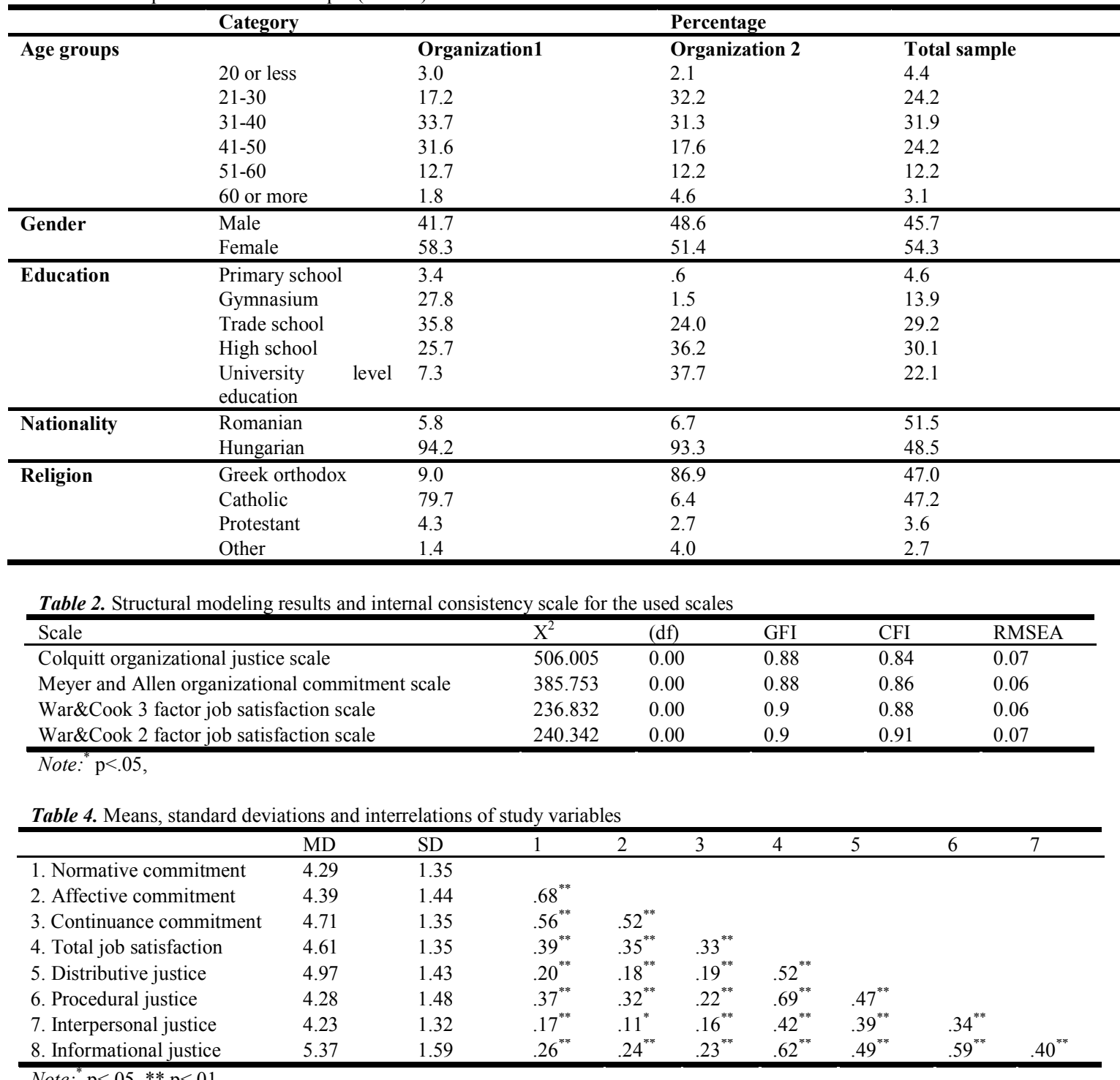

Note: $\mathrm{p}<.05, * * \mathrm{p}<.01$. 
Table 5. Model fit for evaluating the mediating role of total job satisfaction

\begin{tabular}{llllll}
\hline Model & $X^{2}$ & $P$ & $G F I$ & $C F I$ & $R M S E A$ \\
\hline M1A: model with OJ and JS on the same level & 27.193 & $<.01$ & 0.979 & 0.982 & 0.077 \\
M1B: model with JS as mediator including IPJ & 12.738 & $>.05(.254)$ & 0.997 & 0.998 & 0.021 \\
\hline
\end{tabular}

Note: ${ }^{*} p<.05$

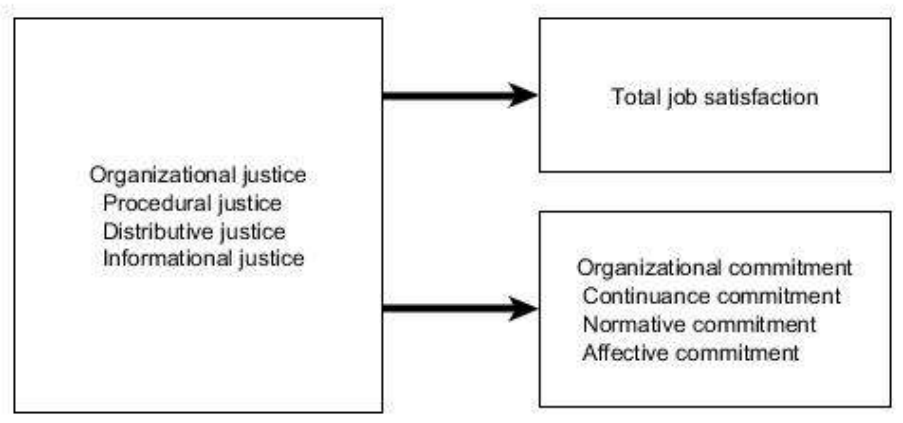

Figure 1. M1A with OJ and JS on the same level

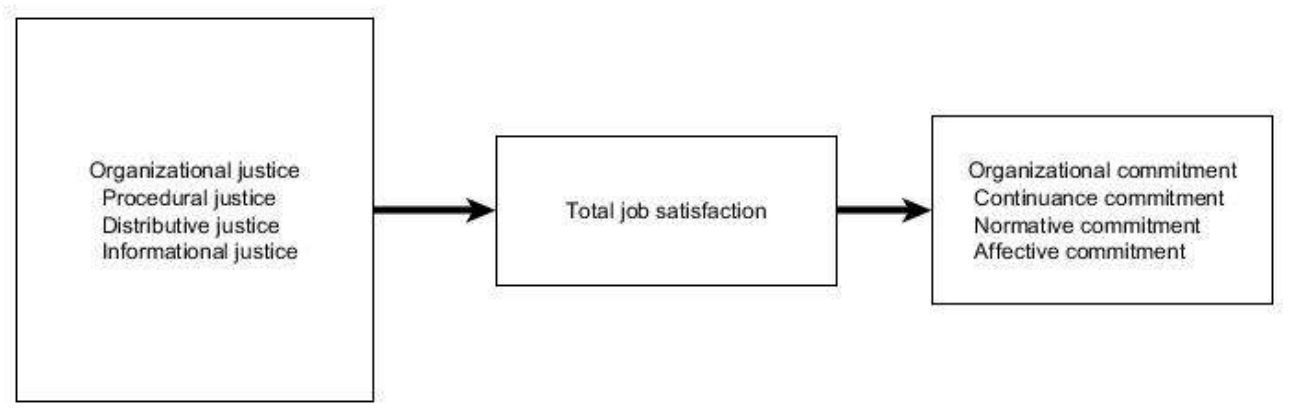

Figure 2. M1B with JS mediating the relation between OJ and OC

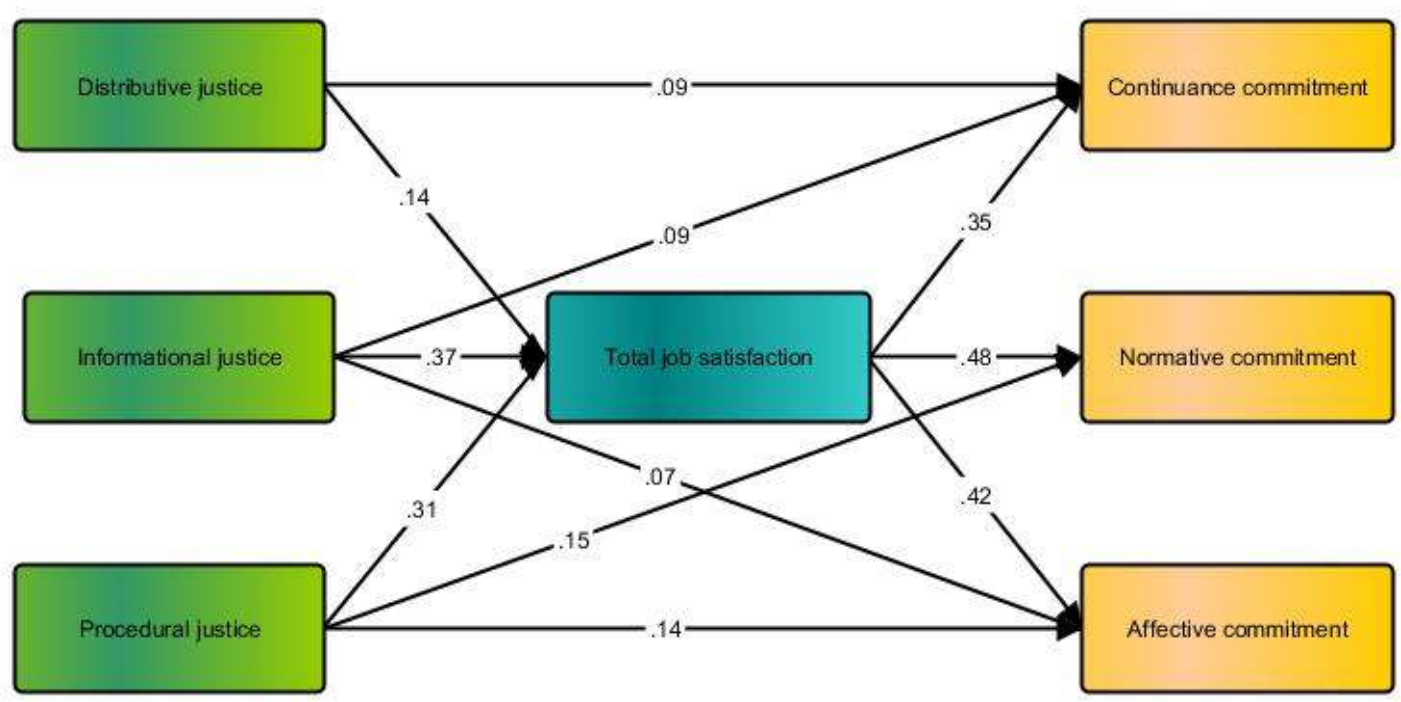

Figure 3. M1B with JS mediating the relation between OJ and OC (dimensions included) 
Table 6.. Standardized and unstandardized regression coefficients for model M2

\begin{tabular}{lllllll}
\hline & & & Estimates & S.E. & P & Standardized estimates \\
\hline Total job satisfaction & $\leftarrow$ & Informational justice & .31 & .02 & $* *$ & .36 \\
Total job satisfaction & $\leftarrow$ & Distributive justice & .12 & .03 & $* *$ & .13 \\
Total job satisfaction & $\leftarrow$ & Procedural justice & .28 & .03 & $* *$ & .3 \\
Normative commitment & $\leftarrow$ & Total job satisfaction & .5 & .03 & $* *$ & .48 \\
Continuance commitment & $\leftarrow$ & Total job satisfaction & .39 & .04 & $* *$ & .35 \\
Affective commitment & $\leftarrow$ & Procedural justice & .13 & .03 & $* *$ & .14 \\
Affective commitment & $\leftarrow$ & Total job satisfaction & .41 & .04 & $* *$ & .41 \\
Continuance commitment & $\leftarrow$ & Informational justice & .08 & .03 & $*$ & .09 \\
Normative commitment & $\leftarrow$ & Procedural justice & .14 & .03 & $* *$ & .15 \\
Continuance commitment & $\leftarrow$ & Distributive justice & .08 & .03 & $*$ & .08 \\
Affective commitment & $\leftarrow$ & Informational justice & .06 & .03 &.$*$ & .07 \\
\hline
\end{tabular}

Note: ${ }^{*}<.05,{ }^{* *} \mathrm{p}<.01$.

Table 7. Standardized total effects model M1B with upper and lower bounds

\begin{tabular}{llccc}
\hline & Procedural justice & Distributive justice & Informational justice & Job satisfaction \\
\hline Job satisfaction & $.3(.24, .36)^{* *}$ & $.14(.07, .2)^{* *}$ & $.36(.31, .43)^{* *}$ & .00 \\
Continuance commitment & $.1(.08, .14)^{* *}$ & $.13(.07, .19)^{* *}$ & $.22(.15, .27)^{* *}$ & $.35(.27, .43)^{* *}$ \\
Affective commitment & $.26(.20, .33)^{* *}$ & $.06(.03, .08)^{* *}$ & $.21(.12, .25)^{* *}$ & $.41(.31, .5)^{* *}$ \\
Normative commitment & $.29(.24, .35)^{* *}$ & $.07(.03, .1)^{* *}$ & $.18(.12, .2)^{* *}$ & $.50(.42, .54)^{* *}$ \\
\hline
\end{tabular}

Note: ${ }^{* * *} p<.01$.

Table 8. Standardized direct effects model M1B with upper and lower bounds

\begin{tabular}{lcccc}
\hline & Procedural justice & Distributive justice & Informational justice & Job satisfaction \\
\hline Job satisfaction & $.3(.24, .36)^{* *}$ & $.13(.08, .2)^{* *}$ & $.36(.31, .43)^{* *}$ & .00 \\
Continuance commitment & .00 & $.08(.03, .13)^{*}$ & $.09(.02, .15)^{*}$ & $.35(.27, .43)^{* *}$ \\
Affective commitment & $.14(.07, .2)^{* *}$ & .00 & $.07(.0, .14) \mathrm{P}>.05$ & $.41(.31, .5)^{* *}$ \\
Normative commitment & $.15(.09, .2)^{* *}$ & .00 & .00 & $.48(.42, .54)^{* *}$ \\
\hline Note: ${ }^{*} \mathrm{p}<.05,{ }^{* *} \mathrm{p}<.01$. & & & &
\end{tabular}

Table 9. Standardized indirect effects and statistical significance for Model M1B

\begin{tabular}{lcccl}
\hline & Procedural justice & Distributive justice & Informational justice & Job satisfaction \\
\hline Job satisfaction & .00 & .00 & .00 & .00 \\
Continuance commitment & $.1(.08, .14) * *$ & $.05(.2, .07) * *$ & $.13(.09, .17)^{* *}$ & .00 \\
Affective commitment & $.12(.09, .16)^{* *}$ & $.06(.03, .09)^{* *}$ & $.15(.1,2)^{* *}$ & .00 \\
Normative commitment & $.14(.11, .18)^{* *}$ & $.07(.03, .1)^{* *}$ & $.18(.14, .22)^{* *}$ & .00 \\
\hline Note: $p<.05, * * \mathrm{p}<.01$ & & & &
\end{tabular}

Table 4 contains correlation estimates, construct means and standard deviations. The correlations between the 8 constructs are at the 0.01 level ( 2 tailed). Normative commitment is correlated with job satisfaction $(r=.396$; $\mathrm{p}<0.01)$, distributive justice $(\mathrm{r}=.206 ; \mathrm{p}<0.01)$, procedural $(r=.373 ; \quad \mathrm{p}<0.01)$ justice, interpersonal justice and informational justice $(\mathrm{r}=.113 ; \mathrm{p}<0.01)$. Affective commitment is correlated with job satisfaction $(\mathrm{r}=.353$; $\mathrm{p}<0.01)$, distributive justice $(\mathrm{r}=.186 ; \mathrm{p}<0.01)$, procedural justice $(\mathrm{r}=.329 ; \mathrm{p}<0.01)$, interpersonal justice $(\mathrm{r}=.113$; $\mathrm{p}<0.01)$ and informational justice $(\mathrm{r}=.245 ; \mathrm{p}<0.01)$. Total job satisfaction is correlated with distributive justice $(\mathrm{r}=.520 ; \mathrm{p}<0.01)$, procedural $(\mathrm{r}=.692 ; \mathrm{p}<0.01)$ justice, interpersonal justice $(\mathrm{r}=.392 ; \mathrm{p}<0.01)$ and informational justice $(\mathrm{r}=.491 ; \mathrm{p}<0.01)$.

The next step was structural equation modeling using AMOS. First we explored the relationship between organizational justice, job satisfaction, and organizational commitment Because of the low $\alpha$ score obtained by the interpersonal justice sub scale the decision was made to eliminate it from the analysis. When constructing the model first we have started from exploring the relations between constructs according to theory. Using job satisfaction as mediator between justice and commitment can be considered unorthodox as most studies consider job satisfaction on the same structural level with commitment (Lee, 2000; Bakhsi, Kumar, \& Rani, 2009; Lambert, Hogan, \& Griffin, 2007; Lowe \& Vodanovich, 1995; Moorman, Niehoff, \& Organ, 1993) with only a few using JS as mediator (Fulford, 2005; Tang \& Strasfield-Baldwin, 1996; Crow, Lee, \& Joo, 2012). To determine whether job satisfaction functions better as a mediator than a construct on the same structural level with commitment, two probable situations were analyzed, one in which the relation between organizational justice and organizational commitment is not mediated by job satisfaction (M1A.), and one in which job satisfaction mediates the relationship between the two constructs (M1B.).

Because model M1B had better statistical indices (see Table 5), it was concluded that for the present date total job satisfaction will fit better as a mediator thus confirming H1. After we have concluded that total job satisfaction is better as a mediator, we have set forth to explore the relations between the dimensions of the concepts. 
To assert which relation between the dimensions of organizational justice and the dimensions of organizational commitment are better mediated total, indirect and direct effect scores were calculated, and then bootstrapping analysis was performed to check for statistical significance (Tables 7, 8 \& 9).

The largest total effect as per model M1B can be observed between procedural justice and normative commitment $(.29 ; .24: .35, \mathrm{p}<.001)$. This relation is composed from a direct effect between procedural justice and normative commitment $(.14 ; .07: .2, \mathrm{p}<.001)$ and an indirect effect mediated by total job satisfaction $(.14 ; .07$ : $.2, p<.001)$. The total effect between procedural justice and affective commitment is of .26 (.2;.33: $\mathrm{p}<.001)$. This relation is composed form a direct relationship between procedural justice and affective commitment of .14 (.07;.2: $\mathrm{p}<.001)$ and an indirect effect of .12 $(.09 ; .16: \mathrm{p}<.001)$ through total job satisfaction. In case of procedural justice the weakest effect can be observed between it and continuance commitment $(.1 ; .08: .14 \mathrm{p}<.001)$ which in this case is a relation completely mediated by total job satisfaction. As a result we can conclude that job satisfaction does mediate the path between procedural justice and all aspects of commitment, even thou only in the case of continuance commitment can we observe full mediation thus we can state that $\mathrm{H} 2$ is confirmed.

In case of distributive justice and aspects of organizational commitment the strongest relation can be found between distributive justice and continuance commitment $(.13 ; .07: .19 \mathrm{p}<.001)$ which is composed of a direct effect $(.08 ; .03, .13: \mathrm{p}<.05)$ and an indirect effect mediated by total job satisfaction of .05 (.02: .07: $\mathrm{p}<.001)$. Concerning the relations between distributive justice normative commitment and affective commitment we only have indirect effects mediated through total job satisfaction (distributive justice-normative commitment .07; .03, .1: $\mathrm{p}<.001$; distributive justice and affective commitment .06 ; $.03, .09: \mathrm{p}<.001$ ). As a result we can conclude that job satisfaction does mediate the relation between distributive justice and all aspects of commitment, path which in case of normative and affective commitment are fully mediated and in case of continuance commitment partially mediated, thus $\mathrm{H} 3$ is confirmed.

Because of the internal consistency issues regarding the interpersonal justice scale we were forced to dismiss $\mathrm{H} 4$.

In case of informational justice the largest total effect in our case was found between it and continuance commitment $(.22 ; .15: .28 \mathrm{p}<.001)$, composed of a direct effect of $.09(.02 ; .15: \mathrm{p}<.05)$ and of an indirect effect mediated by total job satisfaction of .13 (.09:.17: $\mathrm{p}<.001)$. Between informational justice and affective commitment we have a total effect of .21(.15:.29 $\mathrm{p}<.001)$, however in this case the direct effect between it and affective commitment fails to achieve statistical significance thus only the indirect effect of $.15(.1 ; .2: \mathrm{p}<.001)$ mediated by total job satisfaction can be taken into consideration. Between informational justice and normative commitment we have only an indirect effect mediated by total job satisfaction of $.18(.14, .22: \mathrm{p}<.001)$. As a result we can conclude that the relation between informational justice and commitment is also mediated by job satisfaction, where the path between it and continuance commitment is partially mediated, and the path between it and affective and normative commitment is fully mediated by job satisfaction thus $\mathrm{H} 5$ is confirmed.

Based upon model M1B and the results presented in table nr.11 we can state that there is also an unmediated path between procedural justice and affective commitment $(.14 ; .07, .20: \mathrm{p}<.001)$.

\section{Discussion}

In the current study we have focused on verifying the role of total job satisfaction as a mediator between organizational justice and organizational commitment. To establish job satisfaction as a mediator we have put forward two models, one in which job satisfaction is on the same level with organizational commitment and one in which it functions as a mediator between the two concepts. Based upon the results presented above we can state that our results offers support for the role of job satisfaction as mediator between organizational justice and organizational commitment. This is quite a new perspective as most previous studies situate job satisfaction not as a mediator but as a concept on the same structural level with organizational commitment (Lee, 2000; Bakhsi, Kumar, \& Rani, 2009; Lambert, Hogan, \& Griffin, 2007; Lowe \& Vodanovich, 1995; Moorman, Niehoff, \& Organ, 1993) with only a few using JS as mediator (Fulford, 2005; Tang \& Strasfield-Baldwin, 1996; Crow, Lee, \& Joo, 2012). In case of the studies where job satisfaction was treated as a mediator, Fulford's targeted hotel employees in the United States, Tang, Strasfield and Baldwin's was done on employed military veterans also in the United States and Crow, Lee and Joo's had as subjects police officers in South Korea. In all three studies were job satisfaction was treated as a mediator organizational commitment was measured as an aggregate compared with the present study where emphasis was put on the relation between the dimensions of justice and commitment and the way this relation is mediated by job satisfaction. Also when it comes to the relation between organizational justice and job satisfaction, the results are similar with the conclusions of Cohen, Charash and Spector's (2001) meta-analysis that states that organizational justice predicts all types of satisfaction.

However when trying to establish a link between the dimensions of organizational justice and organizational commitment, the mediation is not that clear cut, even though job satisfaction mediates the relation between all the six dimensions of the two concepts, we cannot dismiss the unmediated paths between the concepts presented in our model which are between procedural justice and normative commitment, procedural justice and affective commitment; distributive justice and continuance commitment; and informational justice and continuance commitment. The unmediated relationship found between procedural justice and affective commitment, further enforces the results of the meta-analysis of Cohen, Charash and Spector (2001).

The present model also signals the importance of researching the way in which the 3 dimensions of organizational justice supported by present data are linked through the mediation of job satisfaction to the 3 dimensions of organizational commitment, dynamics which to the best of our knowledge were previously unexplored by research. Thus in our case the strongest relation mediated by job satisfaction (not taking into consideration the direct effect) are between informational justice and normative commitment, informational justice and affective commitment, and by informational justice and continuance commitment. This is followed by the mediated path between procedural justice and normative 
commitment, procedural justice and affective commitment and procedural justice and continuance commitment. The weakest mediated relations are between distributive justice and normative commitment, distributive justice and affective commitment and distributive justice and continuance commitment. These results occupy an intermediary position between the results of Fullford (2005) and those presented by Crow (2012) suggesting that in our case the strongest path mediated by job satisfaction is between interactional justice and commitment, however they also tend to agree with Fullford's position as the second strongest mediation is between procedural justice and commitment. When looking at total effects in our case the strongest total effect can be observed between procedural justice and commitment (normative, affective and then continuance) followed by informational justice and commitment (continuance, affective and normative) and by distributive justice and commitment (continuance, normative and affective), these results being somewhat in line with the ones presented by the meta-analysis of Cohen Charash and Spector (2001), the differences being that in our case although as in the results presented by them, the relation between affective commitment and justice is the strongest the order differs, as based upon our data the most significant total effect was between it and informational justice followed by procedural justice. In our case the second most significant interaction between commitment an justice is between normative commitment and procedural justice, which although indicated by the metaanalysis is in our case more pregnant.

Further directions that can stem from the present study are to see what could be the origins of the reported variation regarding the way in which job satisfaction mediates the relationship between organizational justice and organizational commitment. There is evidence that personal experience (Clay Warner, Hegtvedt, \& Roman, 2005; Lowe \& Vodanovich, A Field study of Distribuitve and Procedural Justice As Predictors of Satisfaction and Organizational Commitment, 1995) can influence the way in which organizational justice relates to organizational commitment thus it wouldn't be farfetched that the previously mentioned variation could also originate from personal experience and why not, the way one perceives his or her surrounding environment.

A methodological issue that arose was the failure to measure interpersonal justice in a statistically significant way by using the scale developed by Roch and Shanock (2006) because of the low $\alpha$ score (.47), thus this dimension had to be dropped from the data analysis. This failure in my opinion is not related to theoretical deficiency of the scale proposed but it has to do more with the personal nature of the questions and the unwillingness of the employees to answer truthfully.

Conclusions, limitations and future research directions

The obtained results according to the presented model suggest that three $(H 1, H 2, H 3$, ) out of five hypothesis were confirmed, thus the present research is among a few that go a step beyond linking organizational justice to organizational commitment, not only enforcing the hypothesis that satisfaction is an important mediator between organizational justice and commitment, but also attempting to observe the way in which the dimension of the two concepts interact with each other. Because of this perspective the presented model was able to capture the fact that even thou satisfaction is an important mediator, not all aspects of organizational commitment were mediated by it.

As in case of all studies the present research has also limitations. The data collected is cross-sectional so causality cannot be established. Also, as McCallum at al. (1993) suggests, alternative models are possible that are indistinguishable from the proposed one; however, based on the presented results and theoretical evidence, we have confidence in the present results.

As a further direction of study we would propose the exploration of how certain personality factors would impact the formation of a certain configurations of organizational justice thus indirectly influence organizational commitment.

\section{References}

Ambrose, M., \& Scminke, M. (2003). Orgaizational Structure as a Moderator of the Relationship Between Procedural Justice, Interactional Justice, Perceived Organizational Support, and Supervisory Trust. Journal of Applied Psychology, 88(2), 295-305. http://dx.doi.org/10.1037/0021-9010.88.2.295

Aryee, S., Budhwar, P. S., \& Chen, Z. X. (2002). Trust as a mediator of the relationship between organizational justice and work outcomes: test of a social exchange model. Journal of Organizational Behavior, 23, 267-285. https://doi.org/10.1002/job.138

Babbie, E. (2008). A mintavétel logikája. In E. Babbie, $A$ társadalomtudomány kutatás gyakorlata (old.: 201-245). Budapest: Balassi Kiadó.

Bakhsi, A., Kumar, K., \& Rani, E. (2009). Organizational Justice Perceptions as Predictor of Job Satisfaction. International Journal of Businsess and Management, 4(9), 145-162.

Bies, R. J., \& Moag, J. F. (1986). Interactional justice: Comunication criteria of fairness. In R. J. Lewicki, B. Sheppard, \& M. Bazerman, Reseach on Negotioations in Organizations (Vol. 1, pp. 43-55). Greenwich: JAI Press Greenwich.

Blau, G., Anderson, L., Davies, K., Daymont, T., Hochner, A., Koziara, K., et al. (2008). The relation between employee organizational and professional developement activities. Vocational Behavior, 72, 123-142. https://doi.org/10.1016/j.jvb.2007.10.004

Byrne, Z. S., Kiersch, C. E., \& Hansen, A. M. (2013). Developement and Validation of an Abridged Measure of Organizational Justice. The Journal of Psychology, 147 (3), https://doi.org/10.1080/00223980.2012.683054

Chang, H.-T., Chi, N.-W., \& Miao, M.-C. (2007). Testing the relationship between three component oorganizational/occupational commitment and organizational/occupational turnover intention using a non-recursive model. Journal of Vocational Behavior, 70, 352-368. https://doi.org/10.1016/j.jvb.2006.10.001

Cheng, S. Y. (2014). The mediating role of organizational justice on the relationship between adminitrative performance appraisal practices and organizational commitment. The International Journal of Human REsource Management, 25(8), 1131-1148. https://doi.org/10.1080/09585192.2013.816864

Clay Warner, J., Hegtvedt, K. A., \& Roman, P. (2005). How Experiences With Downsizing Condition Their Impact On Organizational Commitment. Social Psychology Quarterly, 68(1), 89-102. https://doi.org/10.1177/019027250506800107

Cohen-Charash, Y., \& Spector, P. E. (2001). The Role of Justice in Organizations: A Meta-Analysis. Organizational 
Behavior and Human Decision Process, 86.(2), 278-321. https://doi.org/10.1006/obhd.2001.2958

Cole, M. S., Bernerth, J. B., Walter, F., \& Holr, D. T. (2010, May). Organizational Justice and Individual's Withdrawal; Unlocking the Influence of Emotional Exhaustion. Journal of Management Studies, 47(3), 367-390. https://doi.org/10.1111/j.1467-6486.2009.00864.x

Colquitt, J. A. (2001). On the Dimensionality of Organizational Justice. A Construct Validation of a Measure. Journal of Applied Psychology, 86(3), 386-400.

Colquitt, J. A., Conlon, D. E., Wesson, M. J., Porter, C. O., \& Ng, Y. K. (2001). Justice at the Millenium: A MetaAnalytic Review of 25 Years of ORganizational Justice Research. Journal of Applied Psychology, 86(3), 425-445.

Crow, M. S., Lee, C.-B., \& Joo, J.-J. (2012). ORganizational justice and organizational commitment among South Corean police Officers. Policing: An International Journal of Police Strategies\&Management, 35(2), 402-423. https://doi.org/10.1108/13639511211230156

Darie, A. I. (2011). Justiție organizațională, satisfacție profesională și angajament organizațional în învățământ. Romanian Journal of Applied Psychology, 13(2), 70-78.

Fulford, M. D. (2005). That's Not Fair! The Test of a Model of Organizational Justice, Job Satisfaction and ORganizational Commitment Among Hotel Employees. 4(1), 73-84. https://doi.org/10.1300/J171v04n01 06

Gillet, N., Colombat, P., Micinov, E., Pronost, A.-M., \& Fouquereau, E. (2013). Procedural justice, supervisor autonomy support, work satisfaction ,organizational identification and job performance: the mediating role of need satisfaction and perceived organizational support. Jounral of Advanced Nursing, 69(11), 2560-2571. https://doi.org/10.1111/jan.12144

Greenberg, J. (1986). Determinants of Percieved Fairness of Performance Evaluations. Journal of Applied Psychology, 71(2), 340-342.

Greenberg, J. (1987). A Taxonomy of Organizational Justice Theories. Academy of Management Review, 12(1), 9-22. https://doi.org/10.5465/amr.1987.4306437

Heritage, B., Pollock, C., \& Roberts, L. D. (2015). Confirmatory Factor Analysis of the Warr, Cook, and Wall's (1979) Job Satisfaction Scale. Australian Psychologist, 50(2), 122-129. https://doi.org/10.1111/ap.12103

Hom, P. W., \& Kincki, A. T. (2001). Toward a Greater Understanding of How Dissatisfaction Drives Employee Turnover. The Academy of Management Journal, 44(5), 975-987. https://doi.org/10.5465/3069441

Konovsky, M. A., \& Folger, R. (1989). Effects of Procedural and Distributive Justice on REactions to Pay Raise Decisions. The Academy of Management Journal, 32(1), 115-130. https://doi.org/10.5465/256422

Kwantes, C. T. (2009). Culture, job satisfaction and organziational commitment in India and the United States. Journal of Indian Business Research, 1(4), 196-212. https://doi.org/10.1108/17554190911013265

Lambert, E. G., Hogan, N. L., \& Griffin, M. L. (2007). The impact of distributive and procedural justice on correctional staff. Journal of Crimminal Justice, 35, 644656. https://doi.org/10.1016/j.jcrimjus.2007.09.001

Lee, H.-R. (2000). An Empirical Study of Organizational Justice as Mediator of the Relationship among LeaderMember Excahnge and Job Satisfaction, Oganizational Commitment, and Turnover Intentions in the Lodging Industry. Dissertation sumbitted to the Faculty of the Virginia Plytechnic Institute and State University in partial fulfilment of the required degree of Doctor in Philosophy.

Loi, R., Ngo, H.-Y., \& Foley, S. (2006). Linking employees' justice perceptions to organizational commitment and intention to leave: The mediating role of percieved organizational support. Journal of Ocupational and Organizational Psychology, 79, 101-120. https://doi.org/10.1348/096317905X39657

Lowe, R. H., \& Vodanovich, S. J. (1995). A Field study of Distribuitve and Procedural Justice As Predictors of Satisfaction and Organizational Commitment. Journal of Business and PSychology, 10, 99-118. https://doi.org/10.1007/BF02249273

Ma, L., Xing, Y., Wang, Y., \& Chen, H. (2013). Research on the Relationship among Enterprise Employee's Job Satisfaction, Organizational Commitment and Job Performance. Applied Mechanics and Materials, 411-414, 2477-2480.

https://doi.org/10.4028/www.scientific.net/AMM.411414.2477

MacCallum, R. C., Wegener, T. D., Uchino, B. N., \& Fabrigar, L. R. (1993). The Problem of Equivalent Models in Applications of Covariance Structure Anaysis. Psychological Bulletin, 114(1), 185-199.

Martin, C. L., \& Bennet, N. (1996, March). The Role of Justice Judgements in Explaining the RElationship Between Job Satisfaction and Organizational Commitment. Grup \& Organization Management, 21(1), 84-104. https://doi.org/10.1177/1059601196211005

McFarlin, D. B., \& Sweeney, P. D. (1992). Distributive and Procedural Justice As Predictors of Satisfaction with Personal and ORganizational Outcomes. Academy of Management Journal, 35(3), 626-637. https://doi.org/10.5465/256489

Meyer, J. P., \& Allen, N. J. (1991). A Three-Component Model Conceptualization of Organizational Commitment. Human Resource Management Review, 1(1), 61-89. https://doi.org/10.1016/1053-4822(91)90011-Z

Meyer, J. P., \& Allen, N. J. (2004). Academic Users Guide 2004. The Univeristy of Western Ontario.

Meyer, J. P., Irving, P. G., \& Allen, N. J. (1998). Examination of the combined effects of work values and early work experiences on organizational commitment. Journal of Organizational Behavior, $\quad 19, \quad 29-52$. https://doi.org/10.1002/(SICI)10991379(199801)19:1<29::AID-JOB818>3.0.CO;2-U

Mobely, W. H. (1977). Intermediate Linkages in the Relationship Between Job Satisfaction. Journal of Applied Psychology, 62(2), 237-240. http://dx.doi.org/10.1037/0021-9010.62.2.237

Moorman, R. H., Niehoff, B. P., \& Organ, D. W. (1993). Treating Employees Fairly and Organizationa Citizenship Behavior: Sorting the Effects of Job Satisfaction, Organizational Commitment, and Procedural Justice. Employee Responsibilities and Rights Journal, 6(3), 209225. https://doi.org/10.1007/BF01419445

Moorman, R. H., Niehoff, B. P., \& Organ, D. W. (1993). Treating Employees Fairly and Organizationa Citizenship Behavior: Sorting the Effects of Job Satisfaction, Organizational Commitment, and Procedural Justice. Employee Responsibilities and Rights Journal, 6(3), 209225. https://doi.org/10.1007/BF01419445

Mowday, R. T., Steers, R. M., \& Porter, L. W. (1979). The Measurement of Organizational Commitment. Journal of Vocational Behavior(14), 224-247. https://doi.org/10.1016/0001-8791(79)90072-1

Otto, K., \& Mamatoglu, N. (2015). Why Does Interactional Justice Promote Organizational Loyalty, Job Performance, and Prevent Mental Impairment? The Role of Social Support and Social Stressors. The Journal of Psychology, 2(149), https://doi.org/10.1080/00223980.2013.866535

Pallant, J. (2006). SPSS Survival Manual (Seccond ed.). New York: Open University Press.

Patrick, H. A., \& Sonia, J. (2012). Job Satisfaction and Affective Commitment. The IUP Journal of 
Organizational Behavior, 11(1), 23-36. https://doi.org/10.1177/1359105314521478

Roch, S. G., \& Shanock, L. R. (2006). Organizational Justice in an Exchange Framework: Clarifying Organizational Justice Distinctions. Journal of Management, 32(2), 299322. https://doi.org/10.1177/0149206305280115

Saksvik, I. B., \& Hetland, H. (2011). The role of personality in stress perception across different vocaltional types Journal of employment counseling, 48(1), 3-16. https://doi.org/10.1002/j.2161-1920.2011.tb00106.x

Scmitt, N., \& McCunde, J. T. (1981). The Relationship between Job Attitudes and the Decision to Retire. 24(4), 795-802. https://doi.org/10.5465/256177

Scott, B. A., \& Colquitt, A. J. (2007, June). Are organizational Justice Effects Bounded by Individual Differences? An Examination of Equity Sensitivity, Exchange Ideology and the Big Five. Group\&Organizational Management, 32(3), 290-325. https://doi.org/10.1177/1059601106286877

Tang, L.-P. T., \& Strasfield-Baldwin, L. J. (1996). Distributive and Procedural Justice as related to Satisfaction and Commitment. Advanced Management Journal, 3, 25-43.

Tuzun, I. K. (2009). The Impact of identification and commitment on job satisfcation. The case of a Turkish service provider. Management Research News, 32(8), 728738. https://doi.org/10.1108/01409170910977942
Vereicellino, D. (2008). Satisfactia profesională-teorii si instrumente de măsură. În E. Avram, \& C. L. Cooper, Psihologie organizațional-managerială. Tendințe actuale (pg. 520-577). Iași: Polirom.

Warr, P., Cook, J., \& Wall, T. (1979). Scales for the measurement of some work attitudes ans aspects of psychological well-being. Journal of Occupational Psychology, 52, 129-148. https://doi.org/10.1111/j.20448325.1979.tb00448.x

Yang, J., Peng, K. T., \& Mossholder, K. W. (2004). Procedural Justice Climate and Group Power Distance Orientation: A case of Cross-Level Effects. Academy of Management Proceedings. Vol.2004, No.1, pp. E1-E6. Briarcliff Manor: Academy of Management. http://dx.doi.org/10.1037/0021-9010.92.3.681

Zapata-Phelan, C. P., Colquitt, J. A., Scott, B. A., \& Livingston, B. (2009). Procedural justice, interactional justice, and task perfomrance: The mediating role of intrinsic motivation. Organizational Behavior and Human Decision Processes, 108(1), 93-105. https://doi.org/10.1016/j.obhdp.2008.08.001 